\title{
An Oil Rich in $\gamma$-Linolenic Acid Differently Affects Hepatic Fatty Acid Oxidation in Mice and Rats
}

\author{
Takashi Ide* and Izumi Origuchi ${ }^{\dagger}$ \\ Department of Food and Nutrition, Faculty of Human Life, Jumonji University; 2-1-28 Sugasawa, Niiza, Saitama \\ 352-8510, Japan.
}

Received April 6, 2020; accepted June 12, 2020

The effects of different dietary fats on hepatic fatty acid oxidation were compared in male ICR mice and Sprague-Dawley rats. Animals were fed diets containing $100 \mathrm{~g} / \mathrm{kg}$ of either palm oil (saturated fat), safflower oil (rich in linoleic acid), an oil of evening primrose origin ( $\gamma$-linolenic acid, GLA oil), perilla oil ( $\alpha$-linolenic acid) or fish oil (eicosapentaenoic and doxosahexaenoic acids) for $21 \mathrm{~d}$. GLA, perilla and fish oils, compared with palm and safflower oils, increased the activity of fatty acid oxidation enzymes in both mice and rats, with some exceptions. In mice, GLA and fish oils greatly increased the peroxisomal palmitoyl-CoA oxidation rate, and the activity of acyl-CoA oxidase and enoyl-CoA hydratase to the same degree. The effects were much smaller with perilla oil. In rats, enhancing effects were more notable with fish oil than with GLA and perilla oils, excluding the activity of enoyl-CoA hydratase, and were comparable between GLA and perilla oils. In mice, strong enhancing effects of GLA oil, which were greater than with perilla oil and comparable to those of fish oil, were confirmed on mRNA levels of peroxisomal but not mitochondrial fatty acid oxidation enzymes. In rats, the effects of GLA and perilla oils on mRNA levels of peroxisomal and mitochondrial enzymes were indistinguishable, and lower than those observed with fish oil. Therefore, considerable diversity in the response to dietary polyunsaturated fats, especially the oil rich in $\gamma$-linolenic acid and fish oil, of hepatic fatty acid oxidation pathway exists between mice and rats.

Key words polyunsaturated fat; $\gamma$-linolenic acid; fish oil; hepatic fatty acid oxidation; mouse; rat

\section{INTRODUCTION}

Many studies have suggested that some dietary polyunsaturated fatty acids (PUFAs) influence hepatic fatty acid oxidation. For example, fish oil, and eicosapentaenoic acid (EPA) and docosahexaenoic acid (DHA), which are n-3 PUFAs abundant in fish oil, up-regulate hepatic fatty acid oxidation in rats $^{1-3)}$ and mice. ${ }^{4-6)}$ Perilla and linseed oils rich in $\alpha$-linolenic acid, a n-3 PUFA, also increase the activity and gene expression levels of hepatic enzymes involved in fatty acid oxidation in rats ${ }^{1,7,8)}$ and mice. ${ }^{9,10)}$ Regarding the physiological activity of n-6 PUFAs, we previously reported that safflower oil rich in linoleic acid as well as fungal oil rich in dihomo- $\gamma$-linolenic acid or arachidonic acid had negligible effects on the activity and mRNA levels of enzymes involved in hepatic fatty acid oxidation in rats. ${ }^{1,11)}$ A previous study also found that fungal oil rich in arachidonic acid did not affect the mRNA levels of enzymes involved in fatty acid oxidation in mice. ${ }^{12}$ Regarding the physiological activities of $\gamma$-linolenic acid (GLA), oils rich in GLA were reported to moderately but significantly increase hepatic activity and mRNA levels of some enzymes involved in peroxisomal fatty acid oxidation in rats. ${ }^{13-16)}$ A fungal oil containing $25.3 \%$ GLA, as compared with soybean oil, caused an approximately $39 \%$ increase in the hepatic peroxisomal fatty acid oxidation rate at a dietary level of $4 \%$ in Wistar rats. ${ }^{13)}$ Borage oil containing $25.7 \%$ GLA, as compared with palm oil, caused 43 and $37 \%$ increases in the peroxisomal

TPresent address. Department of Food Sciences, Faculty of Health and $\mathrm{Nu}$ trition, Tokyo Seiei College; 1-4-6 Nishishinkoiwa, Katsushika-ku, Tokyo 124-8530, Japan. fatty acid oxidation rate and activity of acyl-CoA oxidase (the rate-limiting enzyme in peroxisomal fatty acid oxidation), respectively, in the liver of Sprague-Dawley rats at a dietary level of $10 \% \cdot{ }^{14)}$ However, this oil did not affect the mitochondrial fatty acid oxidation rate. Furthermore, borage oil containing different amounts of GLA (24.6 and 46.5\%), as compared with safflower oil, at a dietary level of $20 \%$ caused 19 and $44 \%$ increases, respectively, in the hepatic peroxisomal $\beta$-oxidation rate in the liver of Sprague-Dawley rats. ${ }^{15)}$ Indeed, in this study, borage oil containing different amounts of GLA increased the mRNA levels of acyl-CoA oxidase 1 and bifunctional enzyme (enoyl-CoA hydratase/3-hydroxyacyl CoA dehydrogenase) located in peroxisomes. We also recently demonstrated that an oil of evening primrose origin rich in GLA $(42.6 \%)$, as compared with palm and safflower oils, caused $66-82 \%$ increases in the hepatic peroxisomal fatty acid oxidation rate and $29-42 \%$ increases in acyl-CoA oxidase activity at a dietary level of $10 \%$ in Sprague-Dawley rats. ${ }^{16)}$ These studies demonstrated that dietary GLA can increase hepatic fatty acid oxidation in rats, although its enhancing effects are moderate. However, no previous study that examined the physiological activity of GLA affecting hepatic fatty acid oxidation in mice was found except for our previous study, ${ }^{17}$ ) where we used mice strain null of apolipoprotein E (apoE) expression (BALB/c.KOR/StmSlc Apoe $e^{\text {shl }}$ ). In this study, we examined the physiological activity of an oil of evening primrose origin rich in GLA (42.6\%) affecting hepatic fatty acid oxidation. We observed that an oil rich in GLA, as compared with palm oil and safflower oil, caused a strong dose-dependent increase in the hepatic peroxisomal fatty acid oxidation rate and acyl-CoA oxidase activity in apoE-null mice. The

* To whom correspondence should be addressed. e-mail: t-ide@jumonji-u.ac.jp 
values were more than 5-times higher in the animals fed an oil rich in GLA than in those fed palm or safflower oil at a dietary level of $10 \%$. Therefore, the sensitivity of the hepatic fatty acid oxidation pathway to dietary GLA may be considerably different between mice and rats. In relation to this, it has been reported that species differences exist in physiological responses to some food factors. ${ }^{18,19)}$ Alternatively, the fatty acid oxidation pathway in Apoeshl mice, as compared with other mouse strains, may have a unique propensity to respond to dietary GLA. Therefore, careful examinations are required to draw a definite conclusion on the species differences in the responsiveness of the hepatic fatty acid oxidation pathway to GLA. In addition, no study has compared the physiological activity of polyunsaturated fats with different fatty acid compositions on hepatic fatty acid oxidation between mice and rats. Therefore, we fed mice and rats the diets containing different types of polyunsaturated fats and measured the activity and mRNA levels of enzymes involved in hepatic fatty acid oxidation. In this study, we employed the ICR strain for mice and Sprague-Dawley strain for rats.

\section{MATERIALS AND METHODS}

Animals and Diets Male ICR mice and Sprague-Dawley rats were purchased from Charles River Laboratories Japan, Inc. (Yokohama, Japan) at 4 weeks of age. Animals were housed individually in suspended wire-bottomed stainlesssteel cages in a room with controlled temperature $\left(21-23^{\circ} \mathrm{C}\right)$, humidity (55-65\%), and lighting (lights on from 07:00 to 19:00 h) and fed commercial chow. After $7 \mathrm{~d}$ of acclimatization, animals were randomly divided into five groups of equal mean body weight consisting of 7 animals each and fed the purified experimental diets for $21 \mathrm{~d}$. Experimental diets contained $100 \mathrm{~g} / \mathrm{kg}$ of either palm oil, safflower oil, an oil rich in GLA oil, perilla oil or fish oil. The GLA oil containing $41.8 \%$ GLA made from evening primrose oil was donated by Tama Biochemical Co., Ltd. (Tokyo, Japan). The concentration of GLA is low in natural evening primrose oil (about 10\%). The concentration may be too low to clarify the specific physiological activity of this fatty acid. We therefore employed the GLA oil enriched with GLA in the present study. This oil was prepared by the selective hydrolysis ${ }^{20,21)}$ of evening primrose oil containing 10.5\% GLA using lipase of Candida cylindracea origin and the product was purified through usual oil refining processes (deacidification, deodorization and decoloration). Commercially available edible oils are mostly composed of triacylglycerol and usually contain negligible amounts of partial glycerides. However, GLA oil contained 1.6 and $18.8 \%$ of fatty acid as monoacylglycerol and diacylglycerol (sum of the value of 1,2- and 1,3-diacylglycerols), respectively. ${ }^{16)}$ Safflower oil was also a gift from Tama Biochemical Co., Ltd. Palm, perilla and fish oils were gifts from NOF Co., Ltd. (Tokyo, Japan). The fatty acid compositions of dietary fats were analyzed by GLC using a FAMEWAXTM column $(30 \mathrm{~m} \times 0.25 \mathrm{~mm}$, Restek (Bellefonte, PA, U.S.A.) and are shown in Table 1. The basal composition of purified experimental diet is shown in Table 2. Casein, choline bitartrate and L-cystin were purchased from FUJIFILM Wako Pure Chemical Corporation (Osaka, Japan). Cellulose, and vitamin and mineral mixtures were purchased from Oriental Yeast Co. (Tokyo, Japan). The compositions of vitamin and mineral mixtures were the same as described previously. ${ }^{22)}$ Corn starch and sucrose were purchased from Ikeden Co. (Tokyo, Japan) and Nissin Sugar Co. (Tokyo, Japan), respectively. Animals had free access to the diets and water during the experimental period until they were euthanized. The animal experiments were approved by the review board of animal ethics of Jumonji University (approval number 1604 issued on June 21, 2016 for the mouse study and approval number 1610 issued on January 19, 2017 for the rat study) and we followed the Jumonji University's guidelines for the care and use of experimental animals, the standards relating to the care and keeping and reducing pain of laboratory animals (Notice of the Ministry of the Environment of Japan No. 88 of 2006) as well as the fundamental guidelines for proper conduct of animal experiment and related activities in academic research institutions

Table 1. Fatty Acid Compositions of Dietary Fats

\begin{tabular}{|c|c|c|c|c|c|}
\hline & \multicolumn{5}{|c|}{ Dietary fats } \\
\hline & Palm oil & Safflower oil & GLA oil* & Perilla oil & Fish oil \\
\hline \multicolumn{6}{|c|}{ Fatty acid (g/100 g of total fatty acids) } \\
\hline $14: 0$ & 0.7 & 0.1 & 0.0 & 0.0 & 0.5 \\
\hline $16: 0$ & 43.5 & 6.1 & 4.3 & 5.3 & 14.4 \\
\hline $16: 1(\mathrm{n}-7)$ & 0.1 & 0.0 & 0.0 & 0.0 & 8.0 \\
\hline $18: 0$ & 3.3 & 1.7 & 1.7 & 1.2 & 2.6 \\
\hline $18: 1(n-9)$ & 40.4 & 13.3 & 5.4 & 16.0 & 21.7 \\
\hline $18: 2(\mathrm{n}-6)$ & 11.9 & 78.5 & 46.6 & 13.5 & 2.3 \\
\hline $18: 3(\mathrm{n}-6)$ & 0.0 & 0.2 & 41.8 & 0.0 & 0.2 \\
\hline $18: 3(n-3)$ & 0.1 & 0.2 & 0.2 & 63.9 & 1.0 \\
\hline $20: 3(n-6)$ & 0.0 & 0.0 & 0.0 & 0.0 & 1.8 \\
\hline $20: 4(n-6)$ & 0.0 & 0.0 & 0.0 & 0.0 & 2.2 \\
\hline $20: 5(n-3)$ & 0.0 & 0.0 & 0.0 & 0.0 & 8.6 \\
\hline $22: 4(n-6)$ & 0.0 & 0.0 & 0.0 & 0.0 & 0.6 \\
\hline $22: 5(n-6)$ & 0.0 & 0.0 & 0.0 & 0.0 & 1.2 \\
\hline $22: 5(n-3)$ & 0.0 & 0.0 & 0.0 & 0.0 & 1.5 \\
\hline $22: 6(n-3)$ & 0.0 & 0.0 & 0.0 & 0.0 & 33.1 \\
\hline
\end{tabular}

*An oil rich in $\gamma$-linolenic acid of evening primrose origin. 
(Notice of the Ministry of Education, Culture, Sports, Science and Technology of Japan No. 71 of 2006).

Enzyme Assays At the end of the experiment, animals were anesthetized by isoflurane and euthanized by bleeding from the inferior vena cava from 09:00h to 11:00h, after which the livers were quickly excised. A portion of each liver, approximately 0.6 and $1.5 \mathrm{~g}$ for mice and rats, respectively, was homogenized in 10 volumes of $0.25 \mathrm{M}$ sucrose containing $1 \mathrm{mM}$ ethylenediaminetetraacetic acid (EDTA) and $3 \mathrm{mM}$ Tris- $\mathrm{HCl}$ ( $\mathrm{pH}$ 7.2). The activity of the enzymes involved in fatty acid oxidation was measured using total homogenates as described previously. ${ }^{6}$

RNA Analyses Liver RNA was extracted by the method of Chomczynski and Sacchi. ${ }^{23)}$ The quantity and quality of the RNA were assessed by measuring absorbance at 260, 280 and $320 \mathrm{~nm}$ and by electrophoresis on $1.0 \%$ agarose gels. mRNA abundance was measured using the SYBR Green real-time PCR method. The reaction specificity for this method was verified by a melting curve analysis. mRNA abundance was calculated as a ratio to the mRNA abundance of $\beta$-actin in each cDNA sample and expressed as a fold change, assigning a value of 1 for animals fed a diet containing $100 \mathrm{~g} / \mathrm{kg}$ of palm oil. The nucleotide sequences of PCR primers to analyze mRNA levels in rat liver of $\beta$-actin and fatty acid oxidation enzymes except for carnitine palmitoyltransferase $1 \mathrm{~B}$ have been reported previously. ${ }^{24)}$ Forward and reverse primers for rat carnitine palmitoyltransferase $1 \mathrm{~B}$ were purchased from

Table 2. Composition of Diet

\begin{tabular}{|c|c|}
\hline Ingredidents & $\mathrm{g} / \mathrm{kg}$ \\
\hline Casein & 200 \\
\hline $\mathrm{Oil}^{a)}$ & 100 \\
\hline Corn starch & 150 \\
\hline Sucrose & 479.5 \\
\hline Cellulose & 20.0 \\
\hline Vitamin mixture $^{b)}$ & 10 \\
\hline Mineral mixture ${ }^{c)}$ & 35 \\
\hline Choline bitartrate & 2.5 \\
\hline L-Cystin & 3.0 \\
\hline
\end{tabular}

a) Either palm oil, safflower oil, an oil rich in $\gamma$-linolenic acid, perilla oil or fish oil. b) AIN-93-VX. c) AIN-93G-MX.
TaKaRa Co. (Kyoto, Japan). The nucleotide sequences of primers to analyze mRNAs of mouse genes were designed using Primer Express Software (Applied Biosystems) and are listed in Table 3.

Analyses of Lipids Liver lipids were extracted and purified, ${ }^{25)}$ and triacylglycerol, phospholipid and cholesterol concentrations in the lipid extract were measured as described previously. ${ }^{26)}$ Serum triacylglycerol, cholesterol and phospholipid concentrations were analyzed using commercial enzyme kits purchased from FUJIFILM Wako Pure Chemical Corporation.

Statistical Analysis Microsoft Excel add-in software Excel Statistics 2016 obtained from Social Survey Research Information Co. (Tokyo, Japan) was used for the statistical analysis. Data were expressed as means and their standard errors. The constancy of the variance and normality of the distribution of the observations were evaluated using Levene's test and the Kolmogorov-Smirnov test, respectively. If variances were heterogeneous and/or the distributions were not normal, they were transformed logarithmically. The transformations were successful in rendering the variance of the observations constant and the distribution of data normal, and hence the transformed values were used for subsequent statistical evaluations. Data were analyzed using one-way ANOVA and Tukey's post-hoc test to evaluate significant differences of all means. Differences were considered significant when $p<0.05$.

\section{RESULTS}

Growth Parameters and Liver Weights Fat types did not significantly affect food intake or growth among the groups in both mice and rats (Table 4). In mice, liver weights were the same among the animals fed palm, safflower or perilla oil. The values were significantly higher in mice fed GLA or fish oil than in the other groups. Among rats fed different fats, liver weights were significantly higher in rats fed perilla or fish oil than in those fed safflower or GLA oil. The values in rats fed palm oil were indistinguishable from those in the other groups.

Activity of Enzymes Involved in Hepatic Fatty Acid Oxidation Among the groups of mice, GLA, perilla and fish

Table 3. Nucleotide Sequences of Primers for Real-Time PCR of Mouse mRNAs

\begin{tabular}{|c|c|c|c|c|c|}
\hline $\begin{array}{l}\text { Gene } \\
\text { symbols }\end{array}$ & Genes & Forward primers & Reverse primers & $\begin{array}{l}\text { Length of } \\
\text { PCR products } \\
\text { (bp) }\end{array}$ & $\begin{array}{l}\text { GenBank } \\
\text { accession no. }\end{array}$ \\
\hline Acaalb & Acetyl-CoA acyltransferase 1B & 5'-CCCAGCAGAAGGCAGCAA-3' & 5'-TGGTTGTCACAGGCACAATCTC-3' & 69 & NM_146230 \\
\hline Acaa2 & Acetyl-CoA acyltransferase 2 & 5'-TGCCCCTCAGTTCTTGTCTGT-3' & 5'-GGCGCCTCCACTCACATT-3' & 73 & ВC028901 \\
\hline$A \operatorname{cox} 1$ & Acyl-CoA oxidase 1 & 5'-TTTGTTGTCCCTATCCGTGAGA-3' & 5'-CCGATATCCCCAACAGTGATG-3' & 68 & AB034914 \\
\hline Actb & $\beta$-Actin & 5'-ACGGCCAGGTCATCACTATTG-3' & 5'-CAAGAAGGAAGGCTGGAAAAGA-3' & 71 & NM_007393 \\
\hline Cpt1a & Carnitine palmitoyltransferase $1 \mathrm{~A}$ & 5'-CGATCATCATGACTATGCGCTACT-3' & 5'-GCCGTGCTCTGCAAACATC-3' & 74 & BC046383 \\
\hline Cpt1b & Carnitine palmitoyltransferase 1B & 5'-CCATGGATTTTGTGCTTATTAAGAAC-3' & 5'-TGGCGTGAACGGCATTG-3' & 69 & NM_009948 \\
\hline Cpt2 & Carnitine palmitoyltransferase 2 & 5'-ATCCCCTGGATATGTCCCAATA-3' & 5'-CATCACGACTGGGTTTGGGTAT-3' & 69 & NM_009949 \\
\hline Decr1 & 2,4-Dienoyl-CoA reductase 1 & 5'-CTTGGCAAGGCAATGACAACT-3' & 5'-CAATATTTCTGCTGGCTATCACACA-3' & 70 & NM_026172 \\
\hline Ehhadh & $\begin{array}{l}\text { Enoyl-CoA, hydratase/3-hydroxyacyl-CoA } \\
\text { dehydrogenase }\end{array}$ & 5'-TGGTGATTGGCACCCACTT-3' & 5'-AGTATCGGCTAGGAATGACCTCTAGT-3' & 72 & AK004867 \\
\hline Hadha & Trifunctional protein $\alpha$ subunit & 5'-TGATCGGCATGCACTACTTCTC-3' & 5'-TTGGAGGTTTTGTCAGTGGTGAT-3' & 76 & BC058569 \\
\hline Hadhb & Trifunctional protein $\beta$ subunit & $\begin{array}{c}5^{\prime} \text {-CAGGAAAGGACACAGTTACCAAAGAT } \\
\text { A-3' }\end{array}$ & 5'-GCAGGTTTTAGTTTGGCCATTT-3' & 76 & NM_145558 \\
\hline Pex11a & Peroxisomal biogenesis factor $11 \alpha$ & 5'-GTTCAGACTGGGCAACGTGTT-3' & 5'-GTCAGCGGCTTGGATGCT-3' & 64 & ВC023439 \\
\hline Ppara & $\begin{array}{l}\text { Peroxisome proliferator activated recep- } \\
\text { tor } \alpha\end{array}$ & 5'-CAACGGCGTCGAAGACAAA-3' & 5'-GACGGTCTCCACGGACATG-3' & 73 & NM_011144 \\
\hline
\end{tabular}



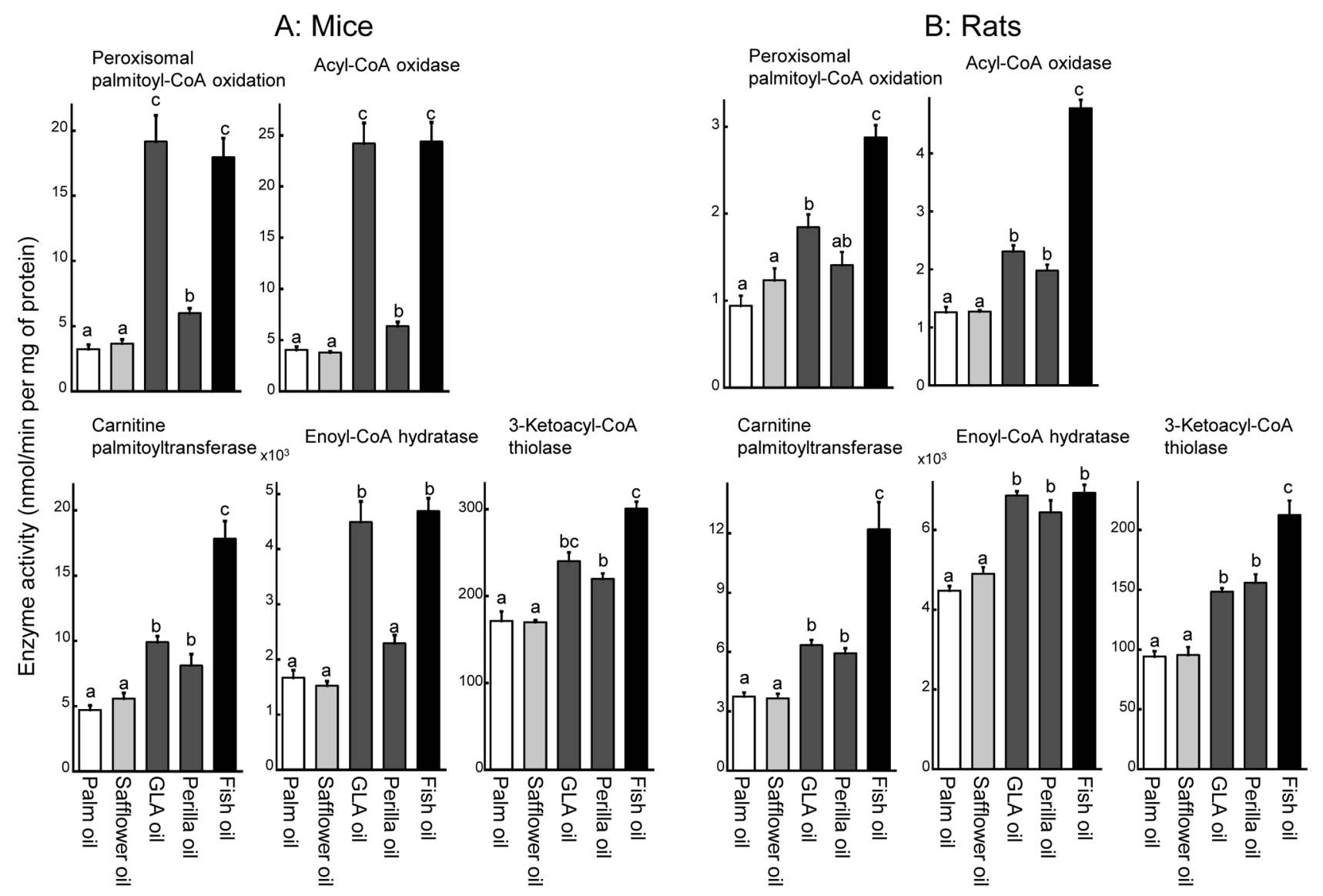

Fig. 1. Effects of Dietary Fats on the Activity of Enzymes Involved in Fatty Acid Oxidation in the Livers of Mice (A) and Rats (B)

Values represent means with their standard errors for $n=7$. Values with different alphabetical letters differ significantly $(p<0.05)$. GLA oil, an oil rich in $\gamma$-linolenic acid of evening primrose origin.

Table 4. Effects of Dietary Fats on Growth Parameters and Liver Weight

\begin{tabular}{|c|c|c|c|c|c|}
\hline & \multicolumn{5}{|c|}{ Dietary fats } \\
\hline & Palm oil & Safflower oil & GLA oil* & Perilla oil & Fish oil \\
\hline \multicolumn{6}{|l|}{ Mice } \\
\hline Food intake (g/d) & $4.77 \pm 0.15$ & $4.59 \pm 0.19$ & $4.46 \pm 0.15$ & $4.31 \pm 0.14$ & $4.19 \pm 0.09$ \\
\hline \multicolumn{6}{|l|}{ Body weight (g) } \\
\hline $0 \mathrm{~d}$ & $28.3 \pm 1.3$ & $28.6 \pm 1.0$ & $28.0 \pm 1.1$ & $27.8 \pm 0.8$ & $27.1 \pm 1.0$ \\
\hline $21 \mathrm{~d}$ & $39.1 \pm 1.5$ & $37.6 \pm 1.4$ & $37.2 \pm 1.3$ & $37.5 \pm 1.3$ & $37.6 \pm 0.5$ \\
\hline Growth $(\mathrm{g} / 21 \mathrm{~d})$ & $10.8 \pm 2.1$ & $9.0 \pm 1.0$ & $9.2 \pm 0.4$ & $9.7 \pm 1.2$ & $10.5 \pm 0.6$ \\
\hline Liver weight ( $g / 100 \mathrm{~g}$ of body weight) & $5.46 \pm 0.19^{\mathrm{a}}$ & $5.52 \pm 0.22^{\mathrm{a}}$ & $6.75 \pm 0.28^{\mathrm{b}}$ & $5.63 \pm 0.18^{\mathrm{a}}$ & $6.63 \pm 0.11^{\mathrm{b}}$ \\
\hline \multicolumn{6}{|l|}{ Rats } \\
\hline Food intake (g/d) & $20.4 \pm 0.5$ & $19.2 \pm 0.7$ & $19.7 \pm 0.6$ & $20.6 \pm 0.7$ & $19.6 \pm 0.4$ \\
\hline \multicolumn{6}{|l|}{ Body weight $(\mathrm{g})$} \\
\hline $0 \mathrm{~d}$ & $119 \pm 3$ & $122 \pm 3$ & $121 \pm 3$ & $125 \pm 3$ & $120 \pm 2$ \\
\hline $21 \mathrm{~d}$ & $300 \pm 7$ & $298 \pm 8$ & $296 \pm 9$ & $322 \pm 6$ & $315 \pm 5$ \\
\hline Growth $(\mathrm{g} / 21 \mathrm{~d})$ & $181 \pm 6$ & $176 \pm 8$ & $176 \pm 7$ & $196 \pm 4$ & $196 \pm 5$ \\
\hline Liver weight ( $\mathrm{g} / 100 \mathrm{~g}$ of body weight) & $5.15 \pm 0.14^{\mathrm{ab}}$ & $4.68 \pm 0.13^{\mathrm{a}}$ & $4.83 \pm 0.13^{\mathrm{a}}$ & $5.24 \pm 0.10^{\mathrm{b}}$ & $5.42 \pm 0.17^{b}$ \\
\hline
\end{tabular}

Values are means \pm S.E.M. for $n=7$. Values in a line not sharing the same superscript letter significantly differ at $p<0.05$. $*$ An oil rich in $\gamma$-linolenic acid of evening primrose origin.

oils, as compared with palm and safflower oils, significantly increased the activity of enzymes involved in hepatic fatty acid oxidation, except in one case for enoyl-CoA hydratase where the value in the animals fed perilla oil was indistinguishable from those in the animals fed palm or safflower oil (Fig. 1A). The increases in the peroxisomal palmitoyl-CoA ox- idation rate, and the activity of acyl-CoA oxidase and enoylCoA hydratase were more marked in mice fed GLA or fish oil than in those fed perilla oil. Fish oil, as compared with other oils, also strongly increased the activity of 3-ketoacyl-CoA thiolase and carnitine palmitoyltransferase. However, GLA oil-dependent increases in these parameters were attenuated. 


\section{A: Mouse}

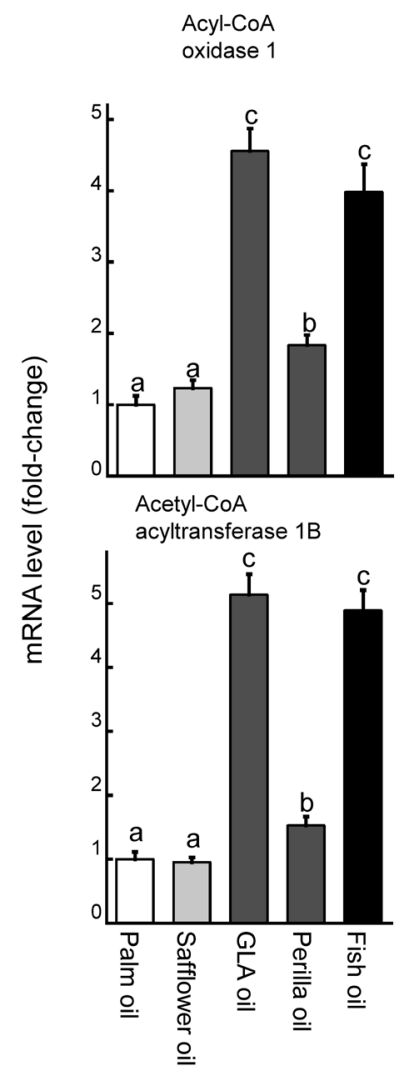

Enoyl-CoA, hydratase/ 3-hydroxyacyl-CoA dehydrogenase

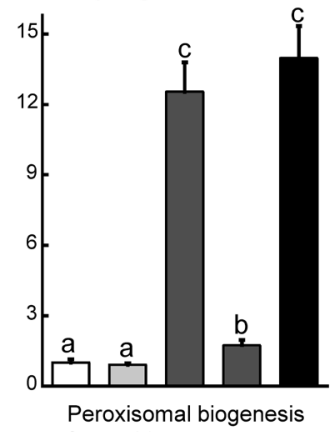

factor $11 \alpha$

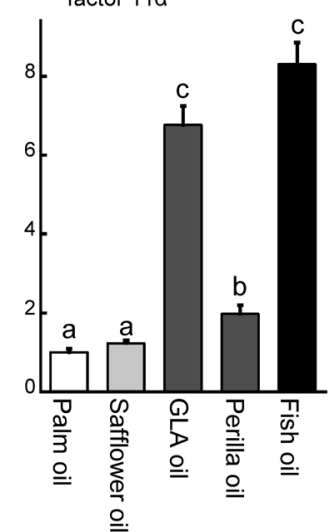

B: Rats

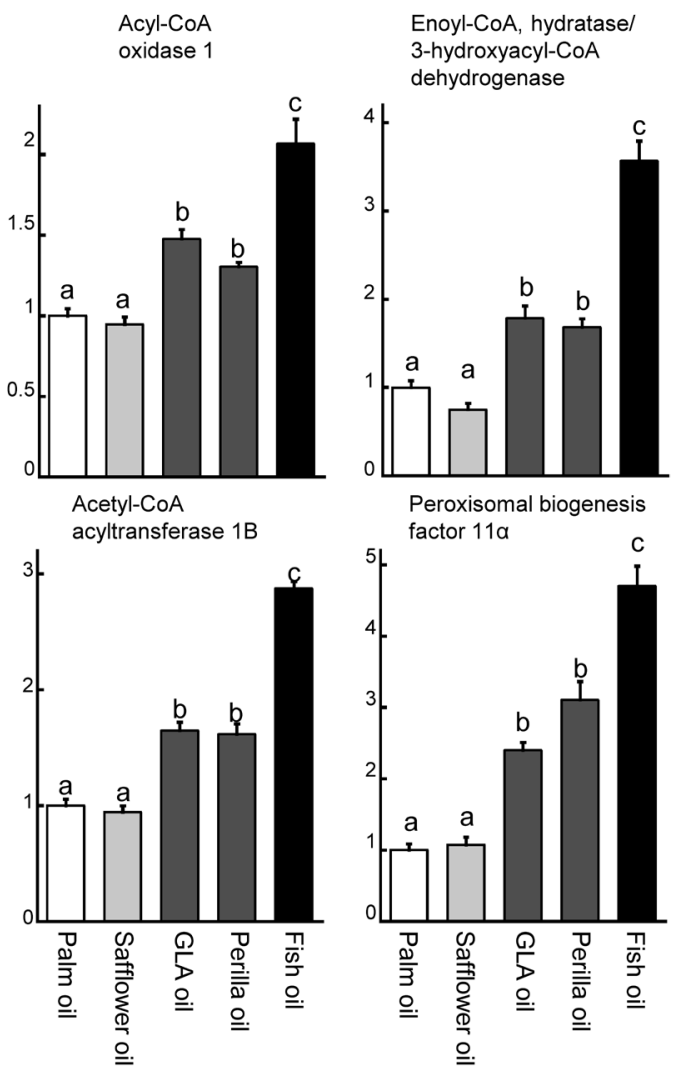

Fig. 2. Effects of Dietary Fats on the mRNA Levels of Peroxisomal Enzymes Involved in Fatty Acid Oxidation and a Peroxisomal Membrane Protein (Peroxisomal Biogenesis Factor $11 \alpha$ ) in the Livers of Mice (A) and Rats (B)

Values represent means with their standard errors for $n=7$. Values with different alphabetical letters differ significantly ( $p<0.05$ ). GLA oil, an oil rich in $\gamma$-linolenic acid of evening primrose origin.

Consequently, these parameters were comparable between mice fed GLA and perilla oils.

The results were considerably different among rats fed different fats (Fig. 1B). Peroxisomal fatty acid oxidation rates and activity levels of acyl-CoA oxidase were considerably lower in rats than in mice. Fish oil, as compared with palm or safflower oil, strongly increased the activity of enzymes involved in hepatic fatty acid oxidation. GLA and perilla oils also increased the enzyme activity but to a lesser extent, except in one case for enoyl-CoA hydratase where the activity levels were the same among rats fed GLA, perilla or fish oil. Unlike in mice, the activity levels of all enzymes involved in hepatic fatty acid oxidation were the same between rats fed GLA oil and perilla oil.

mRNA Levels of Enzymes Involved in Hepatic Peroxisomal and Mitochondrial Fatty Acid Oxidation The mRNA levels of peroxisomal fatty acid oxidation enzymes and a peroxisomal membrane protein, peroxisomal biogenesis factor $11 \alpha(\operatorname{Pex} 11 \alpha)$ in mice are shown in Fig. 2A. GLA, perilla and fish oils, as compared with palm and safflower oils, significantly increased the mRNA levels of peroxisomal fatty acid oxidation enzymes and Pex11 $\alpha$. The increases were more marked with GLA oil or fish oil than with perilla oil. The values observed with GLA and fish oils were comparable. The results in rats are shown in Fig. 2B. Again, GLA, perilla and fish oils, as compared with palm oil or safflower oil, increased the mRNA levels of peroxisomal fatty acid oxidation enzymes and Pex11 $\alpha$. However, unlike in mice, the values were comparable between rats fed GLA and perilla oils. Fish oil was stronger than GLA oil and perilla oil in increasing these values.

The mRNA levels of mitochondrial enzymes involved in fatty acid oxidation in mice are shown in Fig. 3A. GLA, perilla and fish oils, as compared with palm or safflower oil, significantly increased the mRNA levels of various mitochondrial enzymes, except in one case for carnitine palmitoyltransferase 1A where the level in mice fed perilla oil was the same as those in the animals fed palm or safflower oil. The increases were greater with GLA and fish oils than with perilla oil. Indeed, the values were significantly higher in mice fed GLA oil or fish oil than in those fed perilla oil, except in one case for acetyl-CoA acyltransferase 2 where the levels were the same between mice fed GLA and perilla oils. The mRNA levels of different carnitine acyltransferases (carnitine palmitoyltransferase 1A, carnitine palmitoyltransferase $1 \mathrm{~B}$ and carnitine palmitoyltransferase 2) were indistinguishable between mice fed GLA or fish oil. However, the values for trifunctional protein $\alpha$ and $\beta$ subunits, acetyl-CoA acyltransferase 2 and 2,4-dienoyl-CoA reductase 1 were higher in mice fed fish oil than in those fed GLA oil.

In rats, GLA, perilla and fish oils, as compared with palm and safflower oils, also increased the mRNA levels of many mitochondrial enzymes involved in $\beta$-oxidation except for two enzymes (Fig. 3B). Accordingly, these oils were ineffective in increasing the mRNA levels of carnitine palmitoyltransferase 1A. In addition, fish oil but not GLA and perilla oils, as com- 

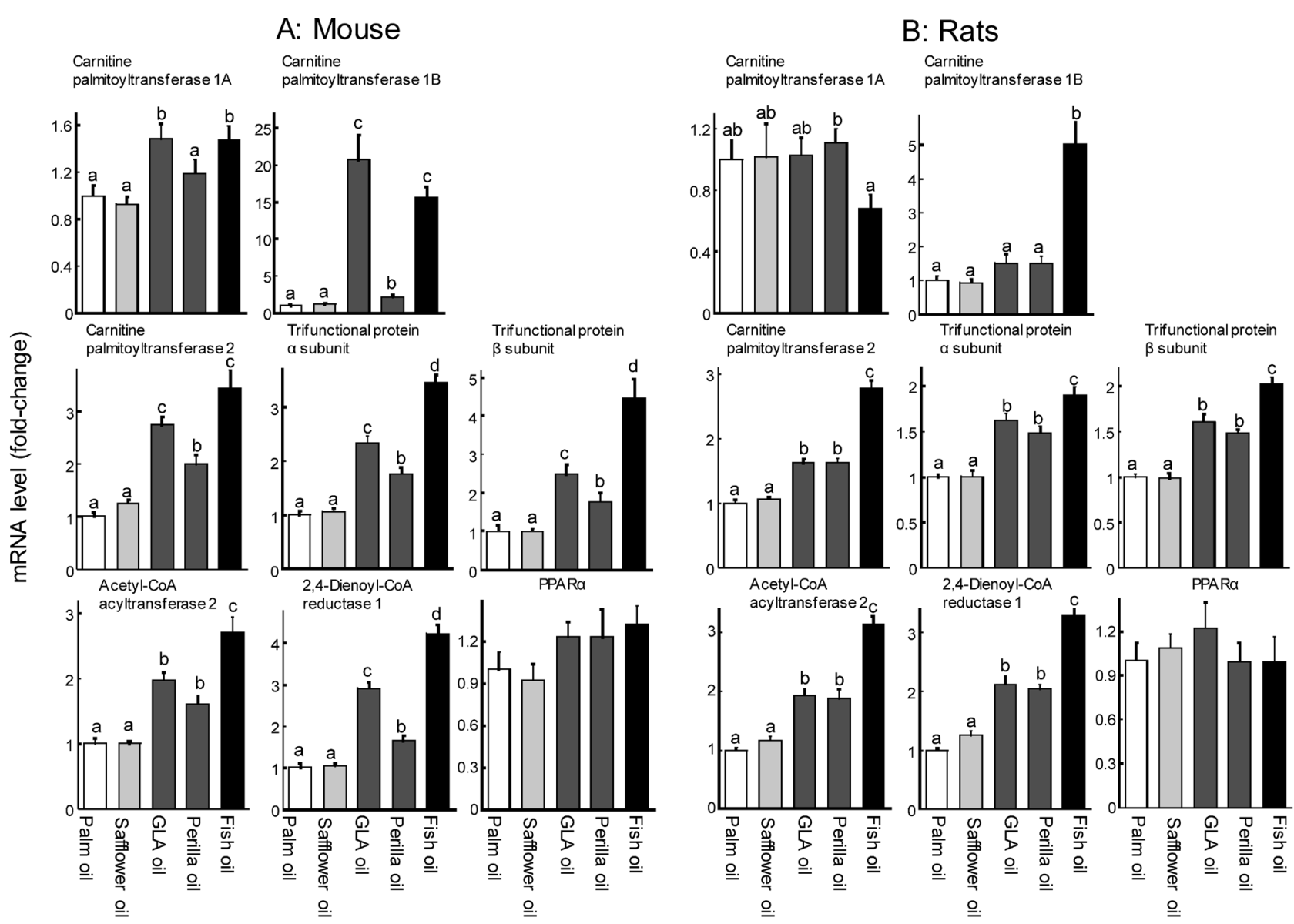

Fig. 3. Effects of Dietary Fats on the mRNA Levels of Mitochondrial Enzymes Involved in Fatty Acid Oxidation and Peroxisome Proliferator Activated Receptor (PPAR) $\alpha$ in the Livers of Mice (A) and Rats (B)

Values represent means with their standard errors for $n=7$. Values with different alphabetical letters differ significantly $(p<0.05)$. GLA oil, an oil rich in $\gamma$-linolenic acid of evening primrose origin.

pared with palm and safflower oils, significantly increased the mRNA levels of carnitine palmitoyltransferase 1B. Fish oil, as compared with GLA and perilla oils, more strongly increased the mRNA levels of mitochondrial fatty acid oxidation enzymes except for carnitine palmitoyltransferase 1A. However, fish oil-dependent increases in these parameters were, in general, considerably more attenuated in rats than in mice. In contrast to mice, there were no significant differences in these parameters between rats fed GLA or perilla oil. We also measured the mRNA levels of peroxisomal proliferator-activated receptor (PPAR) $\alpha$, a transcription factor involved in the regulation of gene expression of fatty acid oxidation enzymes. Types of dietary fats did not affect the values in mice or rats.

Divergent Responses to Dietary Fats of the Enzymes Involved in Fatty Acid Oxidation between Mice and Rats To clarify the divergent responses to different dietary fats of the activity of enzymes involved in fatty acid oxidation between mice and rats, the activity of respective enzymes was first expressed as fold-changes assigning the value of 1.0 to animals fed palm oil. Second, fold-changes obtained in mice were divided by corresponding values obtained in rats. Similar calculations were performed for the mRNA levels of the fatty acid oxidation enzymes (Table 5).

All of the mouse to rat responsiveness ratios to different dietary fats for the activity of fatty acid oxidation enzymes in the animals fed safflower or perilla oil were not significantly different from those in animals fed palm oil and approximated to 1 , indicating that the impact of these dietary fats on the activity of fatty acid oxidation enzymes was similar between mice and rats. The ratios for peroxisomal palmitoyl-CoA oxidation rate and acyl-CoA oxidase activity were much higher in the GLA oil group than in the other oil groups. The ratio for enoyl-CoA hydratase activity was also higher in the GLA oil group than in palm oil, safflower oil and perilla oil groups, but was comparable to that in the animals fed fish oil. However, fat-dependent changes were not observed for the ratios in carnitine palmitoyltransferase activity. The ratio for 3-ketoacyl-CoA thiolase activity was slightly but significantly lower in perilla oil and fish oil groups than in palm oil and safflower oil groups. The ratio in the GLA oil group did not differ from the values in the other groups. Not only GLA oil but also fish oil, as compared with palm oil, safflower oil and perilla oil, gave the higher mouse to rat responsiveness ratios for several enzymes. Indeed, the ratios for the activity of acyl-CoA oxidase and enoyl-CoA hydratase were significantly higher in the fish oil group than in the palm oil, safflower oil and perilla oil groups. In addition, fish oil, as compared to palm and safflower oils, gave the significantly higher mouse to rat responsiveness ratio for peroxisomal palmitoyl-CoA oxidation rate.

Mouse to rat responsiveness ratios for mRNA levels of peroxisomal proteins were significantly higher in the GLA oil group than in the other groups. Fish oil, as compared with 
Table 5. Species Differences of the Responsiveness to Different Fats of the Activity and mRNA Levels of Enzymes Involved in Hepatic Fatty Acid Oxidation (Mouse to Rat Ratio)

\begin{tabular}{|c|c|c|c|c|c|}
\hline & \multicolumn{5}{|c|}{ Dietary fats } \\
\hline & Palm oil & Safflower oil & GLA oil* & Perilla oil & Fish oil \\
\hline \multicolumn{6}{|l|}{ Enzyme activity } \\
\hline Peroxisomal palmitoyl-CoA oxidation & $1.00 \pm 0.11^{\mathrm{a}}$ & $0.860 \pm 0.076^{\mathrm{a}}$ & $2.96 \pm 0.31^{\mathrm{c}}$ & $1.23 \pm 0.08^{\mathrm{ab}}$ & $1.81 \pm 0.15^{\mathrm{b}}$ \\
\hline Acyl-CoA oxidase & $1.00 \pm 0.08^{\mathrm{a}}$ & $0.934 \pm 0.024^{\mathrm{a}}$ & $3.23 \pm 0.26^{\mathrm{c}}$ & $1.00 \pm 0.07^{\mathrm{a}}$ & $1.59 \pm 0.12^{\mathrm{b}}$ \\
\hline Carnitine palmitoyltransferase & $1.00 \pm 0.07$ & $1.21 \pm 0.10$ & $1.25 \pm 0.06$ & $1.09 \pm 0.12$ & $1.16 \pm 0.09$ \\
\hline Enoyl-CoA hydratase & $1.00 \pm 0.08^{\mathrm{a}}$ & $0.834 \pm 0.045^{\mathrm{a}}$ & $1.73 \pm 0.14^{\mathrm{b}}$ & $0.955 \pm 0.061^{\mathrm{e}}$ & $1.81 \pm 0.09^{\mathrm{b}}$ \\
\hline 3-Ketoacyl-CoA thiolase & $1.00 \pm 0.07^{b}$ & $0.978 \pm 0.016^{\mathrm{b}}$ & $0.891 \pm 0.038^{\mathrm{ab}}$ & $0.775 \pm 0.023^{\mathrm{a}}$ & $0.78 \pm 0.02^{\mathrm{a}}$ \\
\hline \multicolumn{6}{|l|}{ mRNA level } \\
\hline \multicolumn{6}{|l|}{ Peroxisomal proteins } \\
\hline Acyl-CoA oxidase 1 & $1.00 \pm 0.12^{\mathrm{a}}$ & $1.31 \pm 0.12^{\mathrm{ab}}$ & $3.12 \pm 0.21^{\mathrm{c}}$ & $1.41 \pm 0.11^{\mathrm{ab}}$ & $1.92 \pm 0.19^{\mathrm{b}}$ \\
\hline $\begin{array}{l}\text { Enoyl-CoA, hydratase/3-hydroxyacyl- } \\
\text { CoA dehydrogenase }\end{array}$ & $1.00 \pm 0.15^{\mathrm{a}}$ & $1.20 \pm 0.09^{\mathrm{a}}$ & $6.84 \pm 0.68^{c}$ & $1.04 \pm 0.13^{\mathrm{a}}$ & $3.92 \pm 0.38^{b}$ \\
\hline Acetyl-CoA acyltransferase $1 \mathrm{~B}$ & $1.00 \pm 0.12^{\mathrm{a}}$ & $1.01 \pm 0.07^{\mathrm{a}}$ & $3.17 \pm 0.19^{\mathrm{c}}$ & $0.948 \pm 0.084^{\mathrm{a}}$ & $1.70 \pm 0.11^{\mathrm{b}}$ \\
\hline Peroxisomal biogenesis factor $11 \alpha$ & $1.00 \pm 0.09^{\mathrm{b}}$ & $1.16 \pm 0.07^{\mathrm{b}}$ & $2.88 \pm 0.20^{\mathrm{d}}$ & $0.637 \pm 0.07^{\mathrm{a}}$ & $1.77 \pm 0.12^{\mathrm{c}}$ \\
\hline \multicolumn{6}{|l|}{ Mitochondrial proteins } \\
\hline Carnitine palmitoyltransferase 1A & $1.00 \pm 0.09^{\mathrm{ab}}$ & $0.920 \pm 0.062^{\mathrm{a}}$ & $1.45 \pm 0.13^{\mathrm{b}}$ & $1.07 \pm 0.11^{\mathrm{ab}}$ & $2.18 \pm 0.18^{\mathrm{c}}$ \\
\hline Carnitine palmitoyltransferase $1 \mathrm{~B}$ & $1.00 \pm 0.10^{\mathrm{a}}$ & $1.20 \pm 0.15^{\mathrm{a}}$ & $12.8 \pm 2.1^{\mathrm{c}}$ & $1.41 \pm 0.22^{\mathrm{a}}$ & $3.14 \pm 0.26^{\mathrm{b}}$ \\
\hline Carnitine palmitoyltransferase 2 & $1.00 \pm 0.08^{\mathrm{a}}$ & $1.17 \pm 0.06^{\mathrm{a}}$ & $1.69 \pm 0.09^{b}$ & $1.22 \pm 0.11^{\mathrm{a}}$ & $1.24 \pm 0.12^{\mathrm{a}}$ \\
\hline Trifunctional protein $\alpha$ subunit & $1.00 \pm 0.07^{\mathrm{a}}$ & $1.06 \pm 0.05^{\mathrm{a}}$ & $1.46 \pm 0.08^{\mathrm{b}}$ & $1.18 \pm 0.09^{\mathrm{ab}}$ & $1.81 \pm 0.08^{\mathrm{c}}$ \\
\hline Trifunctional protein $\beta$ subunit & $1.00 \pm 0.15^{\mathrm{a}}$ & $1.01 \pm 0.07^{\mathrm{a}}$ & $1.56 \pm 0.16^{\mathrm{ab}}$ & $1.19 \pm 0.16^{\mathrm{a}}$ & $2.21 \pm 0.24^{\mathrm{b}}$ \\
\hline Acetyl-CoA acyltransferase 2 & $1.00 \pm 0.09$ & $0.865 \pm 0.036$ & $1.06 \pm 0.06$ & $0.867 \pm 0.062$ & $0.867 \pm 0.073$ \\
\hline 2,4-Dienoyl-CoA reductase 1 & $1.00 \pm 0.10^{\mathrm{a}}$ & $0.830 \pm 0.047^{\mathrm{a}}$ & $1.43 \pm 0.06^{\mathrm{b}}$ & $0.806 \pm 0.055^{\mathrm{a}}$ & $1.287 \pm 0.060^{\mathrm{b}}$ \\
\hline
\end{tabular}

Values are means \pm S.E.M. for $n=7$. Values in a line not sharing the same superscript letter significantly differ at $p<0.05$. ${ }^{*}$ An oil rich in $\gamma$-linolenic acid of evening primrose origin.

palm, safflower and perilla oils, also significantly increased responsiveness ratios for these parameters, except in one case for acyl-CoA oxidase 1 where differences were not significant among fish, perilla and safflower oil groups.

Mouse to rat responsiveness ratios for mRNA levels of various mitochondrial enzymes in safflower and perilla oil groups approximated to 1 and were not significantly different from those in palm oil group. The ratios for many mitochondrial enzymes were generally higher in GLA oil and fish oil group than in palm oil and safflower oil groups. However, species differences in the responses of mitochondrial enzymes were more attenuated than those of peroxisomal proteins except for carnitine palmitoyltransferase $1 \mathrm{~B}$. The mouse to rat responsiveness ratio for this enzyme was significantly higher in GLA oil and fish oil groups than in the other groups, and increase was marked with GLA oil.

Serum and Liver Lipid Levels Serum triacylglycerol levels were lower in mice fed GLA oil or fish oil than in the other groups (Table 6). Also, the levels were lower in mice fed perilla oil than in those fed palm oil or safflower oil. Serum cholesterol levels were lower in mice fed perilla oil or fish oil than in those fed palm oil and safflower oil. The level in mice fed GLA oil was significantly higher than that in the animals fed fish oil but was comparable to those observed in the other groups. Serum phospholipid level was the highest in mice fed palm oil. Safflower oil, as compared with palm oil, had no effect, but other polyunsaturated fats significantly lowered this parameter, with fish oil being the lowest. Different polyunsaturated fats, as compared with palm oil, significantly lowered the hepatic triacylglycerol level in mice. Among the animals fed polyunsaturated fats, the value was the lowest with fish oil, intermediate with GLA oil or perilla oil and the highest with safflower oil. Hepatic cholesterol levels were lower in mice fed GLA oil, perilla oil and fish oil than in those fed palm oil or safflower oil. Hepatic phospholipid concentrations were higher in mice fed GLA oil or fish oil than in those fed palm oil, safflower oil or perilla oil. In rats, GLA, perilla and fish oils, as compared with palm and safflower oils, significantly reduced the serum triacylglycerol concentration. Among rats fed GLA, perilla and fish oils, the concentration was significantly lower in mice fed fish oil than in those fed perilla oil, but the difference was not significant between animals fed fish oil or GLA oil. Serum cholesterol concentration was lower in rats fed fish oil than in those fed palm oil, safflower oil or GLA oil. However, the concentration in the fish oil group was not significantly different from that in the perilla oil group. Serum phospholipid levels were comparable between rats fed palm oil or safflower oil, and these levels were significantly higher than those in the other groups. Among rats fed GLA oil, perilla oil or fish oil, the level was significantly higher in rats fed GLA oil than in those fed fish oil. The level in the perilla oil group was not significantly different from those in the animals fed GLA oil or fish oil. Hepatic triacylglycerol concentration was higher in rats fed palm oil than in the other groups. Among the animals fed different polyunsaturated fats, the concentration was significantly lower in rats fed fish oil than in the other groups. However, no significant differences were detected among rats fed safflower oil, GLA oil or perilla oil. Hepatic cholesterol level was higher in rats fed palm oil than in the other groups. The levels were comparable among the groups of rats fed different polyunsaturated fats. Hepatic phospholipid concentrations were higher in rats fed GLA oil or fish oil than in the other groups. In addition, the concentration was significantly higher in rats fed fish oil than in the animals fed GLA 
oil. The concentrations were comparable among rats fed palm oil, safflower oil or perilla oil.

\section{DISCUSSION}

Previous studies demonstrated that polyunsaturated fats with different fatty acid compositions differently affect hepatic fatty acid oxidation in both mice ${ }^{4-6,9,10,12,17)}$ and rats. ${ }^{1-3,7,8,11,13-16)}$ However, no study has compared the physiological activity of polyunsaturated fats on hepatic fatty acid oxidation between mice and rats. Oils rich in GLA from diverse sources, as compared with saturated fat or oils rich in linoleic acid, increased the activity and mRNA levels of some enzymes involved in hepatic fatty acid oxidation in rats (Wistar or Sprague-Dawley strain) ${ }^{13-16)}$ An increased peroxisomal fatty acid oxidation rate, and increased activity and mRNA levels of enzymes involved in peroxisomal fatty acid oxidation have consistently been reported. ${ }^{13-16)}$ However, the increases in the peroxisomal fatty acid oxidation rate were moderate in these studies (20-80\% increases). No study has examined the physiological activity of oil rich in GLA affecting hepatic fatty acid oxidation in mice except for our previous study using apoE null mice. ${ }^{17)}$ In this study, we found that an oil of evening primrose origin rich in GLA greatly increased hepatic fatty acid oxidation in hyperlipidemic mice of the BALB/c genetic back ground lacking apoE expression (Apoe $\left.e^{\text {shl }}\right)$ (approximately $500 \%$ increase in peroxisomal fatty acid oxidation rate). These results suggested that species differences exist in the response of the fatty acid oxidation pathway to dietary GLA between mice and rats. Using diets of the same compositions and similar experimental conditions, we demonstrated that an oil rich in GLA, as compared with a saturated fat and oils rich in linoleic acid or $\alpha$-linolenic acid, increased peroxisomal fatty acid oxidation rate and the activity of acylCoA oxidase (a rate-limiting enzyme in peroxisomal fatty acid oxidation) more in ICR mice than in Sprague-Dawley rats. An oil rich in $\alpha$-linolenic acid (perilla oil), as compared with palm oil and safflower oil, also increased these values in both mice and rats. However, the values were much higher with an oil rich in GLA than with perilla oil in mice but were comparable with these oils in rats. Moreover, GLA oil-dependent increases in mRNA levels of several enzymes involved in peroxisomal fatty acid oxidation and a peroxisomal membrane protein (peroxisomal biogenesis factor $11 \alpha$ ) were greater in mice than in rats. We also found that an oil rich in GLA, as compared with palm, safflower and perilla oils, significantly increased the mRNA levels of many enzymes involved in mitochondrial fatty acid oxidation in mice. GLA oil and perilla oil, as compared with palm oil and safflower oil, also increased the mRNA levels of many mitochondrial fatty acid oxidation enzymes in rats but, no differences were found between the animals fed these oils. The present study together with our previous studies using mice ${ }^{17)}$ and rats $^{13-16)}$ suggested that a species difference in the responses of the hepatic fatty acid oxidation pathway to dietary GLA exists between mice and rats. However, it is possible that responses of the fatty acid oxidation pathway to dietary polyunsaturated fats differ among animal strains. This needs to be examined using different animal strains. It has been well demonstrated that fish oil or EPA and DHA increase hepatic fatty acid oxidation in both mice $^{4-6)}$ and rats. ${ }^{1-3)}$ This was confirmed in the present study. Moreover, we found that fish oil-dependent increases in many parameters of hepatic fatty acid oxidation were higher in mice than in rats. Therefore, a species difference in the responses of the hepatic fatty acid oxidation pathway to dietary fish oil may also exist between mice and rats.

We previously demonstrated that dietary diacylglycerol increases hepatic fatty acid oxidation in rats. ${ }^{27)}$ GLA oil employed in the present study contained considerable amounts of diacylglycerol. Therefore, it is possible that physiological activity of GLA oil to increase hepatic fatty acid oxidation in mice and rats represents that of diacylglycerol but not of GLA

Table 6. Effects of Dietary Fats on Serum and Liver Lipids

\begin{tabular}{|c|c|c|c|c|c|}
\hline & \multicolumn{5}{|c|}{ Dietary fats } \\
\hline & Palm oil & Safflower oil & GLA oil* & Perilla oil & Fish oil \\
\hline \multicolumn{6}{|l|}{ Mice } \\
\hline \multicolumn{6}{|l|}{ Serum lipids $(\mu \mathrm{mol} / \mathrm{dL})$} \\
\hline Triacylglycerol & $181 \pm 16^{\mathrm{c}}$ & $168 \pm 10^{c}$ & $58.7 \pm 4.2^{\mathrm{a}}$ & $112 \pm 6^{b}$ & $43.8 \pm 8.4^{\mathrm{a}}$ \\
\hline Cholesterol & $537 \pm 36^{\mathrm{c}}$ & $486 \pm 46^{c}$ & $460 \pm 27^{\mathrm{bc}}$ & $357 \pm 16^{\mathrm{ab}}$ & $231 \pm 15^{\mathrm{a}}$ \\
\hline Phospholipid & $552 \pm 23^{\mathrm{d}}$ & $457 \pm 41^{\mathrm{cd}}$ & $370 \pm 17^{\mathrm{bc}}$ & $314 \pm 15^{\mathrm{b}}$ & $177 \pm 11^{\mathrm{a}}$ \\
\hline \multicolumn{6}{|l|}{ Liver lipids $(\mu \mathrm{mol} / \mathrm{g})$} \\
\hline Triacylglycerol & $78.2 \pm 6.9^{\mathrm{d}}$ & $43.7 \pm 5.0^{\mathrm{c}}$ & $27.7 \pm 1.5^{\mathrm{b}}$ & $21.8 \pm 1.6^{\mathrm{b}}$ & $13.0 \pm 1.6^{\mathrm{a}}$ \\
\hline Cholesterol & $7.13 \pm 0.22^{b}$ & $6.33 \pm 0.44^{b}$ & $4.36 \pm 0.13^{\mathrm{a}}$ & $4.87 \pm 0.15^{\mathrm{a}}$ & $4.13 \pm 0.10^{\mathrm{a}}$ \\
\hline Phospholipid & $39.6 \pm 1.2^{\mathrm{a}}$ & $41.4 \pm 1.3^{\mathrm{a}}$ & $49.2 \pm 0.6^{\mathrm{b}}$ & $42.4 \pm 0.6^{\mathrm{a}}$ & $50.5 \pm 0.7^{\mathrm{b}}$ \\
\hline \multicolumn{6}{|l|}{ Rats } \\
\hline \multicolumn{6}{|c|}{ Serum lipids $(\mu \mathrm{mol} / \mathrm{dL})$} \\
\hline Triacylglycerol & $332 \pm 23^{c}$ & $259 \pm 39^{c}$ & $121 \pm 8^{\mathrm{ab}}$ & $141 \pm 20^{\mathrm{b}}$ & $81.6 \pm 9.3^{\mathrm{a}}$ \\
\hline Cholesterol & $241 \pm 16^{\mathrm{c}}$ & $194 \pm 11^{b c}$ & $209 \pm 17^{\mathrm{bc}}$ & $164 \pm 13^{\mathrm{ab}}$ & $120 \pm 10^{\mathrm{a}}$ \\
\hline Phospholipid & $287 \pm 14^{\mathrm{c}}$ & $250 \pm 22^{\mathrm{c}}$ & $187 \pm 10^{\mathrm{b}}$ & $161 \pm 4^{\mathrm{ab}}$ & $123 \pm 7^{\mathrm{a}}$ \\
\hline \multicolumn{6}{|l|}{ Liver lipids $(\mu \mathrm{mol} / \mathrm{g})$} \\
\hline Triacylglycerol & $66.8 \pm 12.1^{\mathrm{c}}$ & $29.1 \pm 1.9^{\mathrm{b}}$ & $20.4 \pm 0.5^{\mathrm{b}}$ & $23.3 \pm 1.0^{\mathrm{b}}$ & $11.3 \pm 0.9^{\mathrm{a}}$ \\
\hline Cholesterol & $6.50 \pm 0.49^{b}$ & $5.19 \pm 0.10^{\mathrm{a}}$ & $4.87 \pm 0.17^{\mathrm{a}}$ & $5.00 \pm 0.17^{\mathrm{a}}$ & $4.93 \pm 0.13^{\mathrm{a}}$ \\
\hline Phospholipid & $38.5 \pm 1.0^{\mathrm{a}}$ & $38.8 \pm 0.7^{\mathrm{a}}$ & $42.9 \pm 0.5^{\mathrm{b}}$ & $38.3 \pm 0.7^{\mathrm{a}}$ & $46.5 \pm 0.8^{c}$ \\
\hline
\end{tabular}

Values are means \pm S.E.M. for $n=7$. Values in a line not sharing the same superscript letter significantly differ at $p<0.05$. An oil rich in $\gamma$-linolenic acid of evening primrose origin. 
per se. However, the amounts of diacylglycerol in GLA oil may be too low to affect hepatic fatty acid oxidation, if any, at least in rats. ${ }^{27)}$ In addition, a previous study ${ }^{28)}$ has indicated that dietary diacylglycerol did not affect hepatic fatty acid oxidation in $\mathrm{C} 57 \mathrm{BL} / \mathrm{KsJ}-\mathrm{db} / \mathrm{db}$ mice. Therefore, it is difficult to consider that diacylglycerol in GLA oil preparation is primarily responsible for the increases in hepatic fatty acid oxidation in mice and rats observed in the present study.

There is the possibility that some minor components other than fatty acids is involved in the physiological activity of GLA oil to increase hepatic fatty acid oxidation. In relation to this, it has been reported that among various type of plant oils, phytosterol contents are much higher in evening primrose oil than in the others. ${ }^{29,30)}$ GLA oil made of evening primrose oil used in the present study contained considerable amounts of unsaponifiable matter (1.8\%) mainly as phytosterol esters (maker's statement). The vale is much higher than those reported for other edible oils $(0.05-1 \%){ }^{29,30)}$ However, it is rather difficult to consider that phytosterols are responsible for the propensity of GLA oil to increase hepatic fatty acid oxidation. No study has hitherto revealed that dietary phytosterols enhance hepatic fatty acid oxidation in experimental animals. $^{31,32)}$

PPAR $\alpha$ is a transcription factor involved in the regulation of the gene expression of the enzymes involved in hepatic fatty acid oxidation, ${ }^{33)}$ and many fatty acids act as ligands and activators of this transcription factor. ${ }^{34-36)}$ Regarding the mechanisms causing the species difference in the responsiveness of hepatic fatty acid oxidation to dietary fat, the divergencies in ligand specificities was reported among PPAR $\alpha$ of human, rat and murine origins. ${ }^{34,35)}$ However, considering the reported data on this topic, this mechanism alone cannot account for the species difference in the responses of the hepatic fatty acid oxidation pathway to dietary fats observed in this study. Therefore, other mechanisms should be considered based on the results of the present study. There is the possibility that the differences in the structures of promoter regions of genes involved in the regulation of fatty acid oxidation between mice and rats may be responsible for the observation made in the present study. However, the information on this topic has been scarce.

In our present study, GLA oil-dependent increases in mRNA levels were generally stronger for peroxisomal enzymes than for mitochondrial enzymes in mice. Fish oil, on the other hand, greatly increased the mRNA levels of both peroxisomal and mitochondrial enzymes in mice. A study in $\operatorname{PPAR} \alpha$-null mice ${ }^{37)}$ confirmed that many hepatic fatty acid oxidation enzymes located in mitochondria and peroxisomes are controlled by $\operatorname{PPAR} \alpha$. Moreover, both peroxisomal and mitochondrial fatty acid oxidation enzymes in rats are also controlled by PPAR $\alpha^{33,38,39)}$ Although many fatty acid species can activate PPAR $\alpha$, the mechanism by which dietary GLA oil caused greater increases in the parameters of peroxisomal fatty oxidation than in those of mitochondrial fatty acid oxidation in mice is not clear at present.

GLA oil- and fish oil-dependent increases in mRNA levels of carnitine palmitoyltransferase $1 \mathrm{~B}$ were markedly large among mitochondrial enzymes in mice. Although GLA oil did not increase the mRNA levels of carnitine palmitoyltransferase $1 \mathrm{~B}$ in rats, the fish oil-dependent increase in this parameter was significantly high among mitochondrial enzymes.
Carnitine palmitoyltransferase $1 \mathrm{~B}$ is a protein homologous to carnitine palmitoyltransferase $1 \mathrm{~A} .{ }^{40)}$ Northern blot analysis and etomoxir-CoA (an agent that specifically binds to carnitine palmitoyltransferase 1) labelling technique revealed that both isoforms are expressed widely among the rat tissues. ${ }^{41)}$ Although these techniques identified carnitine palmitoyltransferase $1 \mathrm{~A}$ in the liver, they failed to detect the $1 \mathrm{~B}$ isoform in this tissue. Therefore, carnitine palmitoyltransferase $1 \mathrm{~A}$ but not $1 \mathrm{~B}$ is considered to function in the regulation of hepatic fatty acid oxidation in the liver. Real-time PCR performed in this study confirmed mRNA expression of the $1 \mathrm{~B}$ isoform in the livers of mice and rats, and we found that types of dietary fat markedly affected the levels, especially in mice. This suggests that not only $1 \mathrm{~A}$ but also $1 \mathrm{~B}$ isoforms plays significant role in polyunsaturated fat-dependent regulation of hepatic fatty acid oxidation. Although both GLA oil and fish oil also increased mRNA levels of carnitine palmitoyltransferase 1A in mice, the increases were small. In addition, the polyunsaturated fats had no effect on the mRNA levels of the $1 \mathrm{~A}$ isoform in rats. These results were, in general, consistent with those reported previously in mice ${ }^{6,17,42,43)}$ and rats. ${ }^{1,2,16,44)}$ In this context, fatty acids can activate human carnitines palmitoyltransferase $1 \mathrm{~B}$ gene through the PPAR-dependent mechanism. ${ }^{45}$ ) In contrast, Louet et al. $^{46)}$ reported that a PPAR-independent mechanism is involved in regulating mRNA expression of the $1 \mathrm{~A}$ isoform.

Changes in hepatic fatty acid oxidation affect the availability of fatty acids for triacylglycerol synthesis, and in turn alter the production of very low-density lipoproteins, and hence, the serum triacylglycerol concentration. ${ }^{47,48)}$ Consistent with this, alterations by dietary fats of the indices of hepatic fatty acid oxidation were, in general, inversely correlated with the changes in the serum triacylglycerol concentration in both mice and rats. Such a correlation was not observed between the concentration of serum cholesterol or phospholipid, and indices of hepatic fatty acid oxidation. As these lipids are mostly associated with low-density and high-density lipoproteins, dietary fats may have exerted different effects on the metabolism of these lipoproteins. Hepatic triacylglycerol concentration was not well correlated well with the changes in hepatic fatty acid oxidation. Changes in other metabolic processes such as lipogenesis ${ }^{1,2,4,6)}$ and transporter-mediated uptake of fatty acids, ${ }^{49}$ ) should also be taken into consideration. Indeed, previous studies reported that the dietary fat amount or type affect the gene expression of CD36, a fatty acid transporter located in the plasma membrane, in the livers of mice ${ }^{50-52)}$ and rats. ${ }^{53)}$ Among different polyunsaturated fats, fish oil caused the lowest hepatic triacylglycerol concentration in both mice and rats. In relation to this, it has been well demonstrated that fish oil strongly reduces hepatic lipogenesis in both mice $^{4,6)}$ and rats. ${ }^{1,2)}$

In conclusion, there is considerable divergence in the responsiveness of the hepatic fatty acid oxidation pathway to dietary polyunsaturated fats between mice and rats. Therefore, care should be taken when extrapolating effects of dietary fats on hepatic fatty acid oxidation in animals to humans.

Acknowledgments This research was funded by a Grantin-Aid for scientific research (Scientific Research C, No. 22580143) from the Japan Society for the Promotion of Science. Expert technical assistances by Yu Uchiyama, Yukako 
Yasuda, Noe Yamaguchi and Marino Yamamichi were greatly appreciated.

Conflict of Interest The authors declare no conflict of interest.

\section{REFERENCES}

1) Ide T, Kobayashi H, Ashakumary L, Rouyer IA, Takahashi Y, Aoyama T, Hashimoto T, Mizugaki M. Comparative effects of perilla and fish oils on the activity and gene expression of fatty acid oxidation enzymes in rat liver. Biochim. Biophys. Acta, 1485, 23-35 (2000).

2) Hong DD, Takahashi Y, Kushiro M, Ide T. Divergent effects of eicosapentaenoic and docosahexaenoic acid ethyl esters, and fish oil on hepatic fatty acid oxidation in the rat. Biochim. Biophys. Acta, 1635, 29-36 (2003).

3) Willumsen N, Skorve J, Hexeberg S, Rustan AC, Berge RK. The hypotriglyceridemic effect of eicosapentaenoic acid in rats is reflected in increased mitochondrial fatty acid oxidation followed by diminished lipogenesis. Lipids, 28, 683-690 (1993).

4) Bargut TC, Frantz ED, Mandarim-de-Lacerda CA, Aguila MB. Effects of a diet rich in $n-3$ polyunsaturated fatty acids on hepatic lipogenesis and beta-oxidation in mice. Lipids, 49, 431-444 (2014).

5) Du ZY, Ma T, Liaset B, Keenan AH, Araujo P, Lock EJ, Demizieux L, Degrace P, Frøyland L, Kristiansen K, Madsen L. Dietary eicosapentaenoic acid supplementation accentuates hepatic triglyceride accumulation in mice with impaired fatty acid oxidation capacity. Biochim. Biophys. Acta, 1831, 291-299 (2013).

6) Ide T, Takahashi Y, Kushiro M, Tachibana M, Matsushima Y. Effect of n-3 fatty acids on serum lipid levels and hepatic fatty acid metabolism in BALB/c.KOR-Apoe $e^{\text {shl }}$ mice deficient in apolipoprotein E expression. J. Nutr. Biochem., 15, 169-178 (2004).

7) Ide T, Murata M, Sugano M. Stimulation of the activities of hepatic fatty acid oxidation enzymes by dietary fat rich in $\alpha$-linolenic acid in rats. J. Lipid Res., 37, 448-463 (1996).

8) Kabir Y, Ide T. Activity of hepatic fatty acid oxidation enzymes in rats fed $\alpha$-linolenic acid. Biochim. Biophys. Acta, 1304, 105-119 (1996).

9) Morise A, Thomas C, Landrier JF, Besnard P, Hermier D. Hepatic lipid metabolism response to dietary fatty acids is differently modulated by PPAR $\alpha$ in male and female mice. Eur. J. Nutr., 48, 465-473 (2009).

10) Javadi M, Geelen MJ, Lemmens AG, Lankhorst A, Schonewille JT, Terpstra AH, Beynen AC. The influence of dietary linoleic and $\alpha$-linolenic acid on body composition and the activities of key enzymes of hepatic lipogenesis and fatty acid oxidation in mice. $J$. Anim. Physiol. Anim. Nutr. (Berl.), 91, 11-18 (2007).

11) Ide $\mathrm{T}$, Ono $\mathrm{Y}$, Kawashima $\mathrm{H}$, Kiso $\mathrm{Y}$. Interrelated effects of dihomo- $\gamma$-linolenic and arachidonic acids, and sesamin on hepatic fatty acid synthesis and oxidation in rats. Br. J. Nutr., 108, 19801993 (2012).

12) Berger A, Mutch DM, German JB, Roberts MA. Dietary effects of arachidonate-rich fungal oil and fish oil on murine hepatic and hippocampal gene expression. Lipids Health Dis., 1, 2 (2002).

13) Takada R, Saitoh M, Mori T. Dietary $\gamma$-linolenic acid-enriched oil reduces body fat content and induces liver enzyme activities relating to fatty acid $\beta$-oxidation in rats. J. Nutr., 124, 469-474 (1994).

14) Kumamoto T, Ide T. Comparative effects of $\alpha$ - and $\gamma$-linolenic acids on rat liver fatty acid oxidation. Lipids, 33, 647-654 (1998).

15) Takahashi Y, Ide T, Fujita H. Dietary $\gamma$-linolenic acid in the form of borage oil causes less body fat accumulation accompanying an increase in uncoupling protein 1 mRNA level in brown adipose tissue. Comp. Biochem. Physiol. B Biochem. Mol. Biol., 127, 213-222 (2000).

16) Ide T, Iwase H, Amano S, Sunahara S, Tachihara A, Yagi M,
Watanabe T. Physiological effects of $\gamma$-linolenic acid and sesamin on hepatic fatty acid synthesis and oxidation. J. Nutr. Biochem., 41, 42-55 (2017).

17) Ide T, Origuchi I. Physiological effects of an oil rich in $\gamma$-linolenic acid on hepatic fatty acid oxidation and serum lipid levels in genetically hyperlipidemic mice. J. Clin. Biochem. Nutr., 64, 148-157 (2019).

18) Moya-Camarena SY, Belury MA. Species differences in the metabolism and regulation of gene expression by conjugated linoleic acid. Nutr. Rev., 57, 336-340 (1999).

19) Kushiro M, Takahashi Y, Ide T. Species differences in the physiological activity of dietary lignan (sesamin and episesamin) in affecting hepatic fatty acid metabolism. Br. J. Nutr., 91, 377-386 (2004).

20) Syed Rahmatullah MSK, Shukla VKS, Mukherjee KD. Enrichment of $\gamma$-linolenic acid from evening primrose oil and borage oil via lipase-catalyzed hydrolysis. J. Am. Oil Chem. Soc., 71, 569-573 (1994).

21) Shimada Y, Fukushima N, Fujita H, Honda Y, Sugihara A, Tominaga Y. Selective hydrolysis of borage oil with Candida rugosa lipase: Two factors affecting the reaction. J. Am. Oil Chem. Soc., 75, $1581-1586$ (1998)

22) Reeves PG, Nielsen FH, Fahey GC Jr. AIN-93 purified diets for laboratory rodents: final report of the American Institute of Nutrition ad hoc writing committee on the reformulation of the AIN-76A rodent diet. J. Nutr., 123, 1939-1951 (1993).

23) Chomczynski P, Sacchi N. Single-step method of RNA isolation by acid guanidium thiocyanate-phenol-chloroform extraction. Anal. Biochem., 162, 156-159 (1987)

24) Lim JS, Adachi Y, Takahashi Y, Ide T. Comparative analysis of sesame lignans (sesamin and sesamolin) in affecting hepatic fatty acid metabolism in rats. Br. J. Nutr., 97, 85-95 (2007).

25) Folch J, Lees M, Sloane Stanley GH. A simple method for the isolation and purification of total lipides from animal tissues. J. Biol. Chem., 226, 497-509 (1957).

26) Ide T, Okamatsu H, Sugano M. Regulation by dietary fats of 3-hydroxy-3-methylglutaryl-Coenzyme A reductase in rat liver. J. Nutr., 108, 601-612 (1978).

27) Murata M, Ide T, Hara K. Reciprocal responses to dietary diacylglycerol of hepatic enzymes of fatty acid synthesis and oxidation in the rat. Br. J. Nutr., 77, 107-121 (1997).

28) Murase T, Nagasawa A, Suzuki J, Wakisaka T, Hase T, Tokimitsu I. Dietary $\alpha$-linolenic acid-rich diacylglycerols reduce body weight gain accompanying the stimulation of intestinal $\beta$-oxidation and related gene expressions in $\mathrm{C} 57 \mathrm{BL} / \mathrm{KsJ}-\mathrm{db} / \mathrm{db}$ mice. J. Nutr., 132, 3018-3022 (2002).

29) Phillips KM, Ruggio DM, Toivo JI, Swank MA, Simpkins AH. Free and esterified sterol composition of edible oils and fats. J. Food Compos. Anal., 15, 123-142 (2002).

30) Yang R, Xue L, Zhang L, Wang X, Qi X, Jiang J, Yu L, Wang X, Zhang W, Zhang Q, Li P. Phytosterol contents of edible oils and their contributions to estimated phytosterol intake in the chinese diet. Foods, 8, 334 (2019).

31) Moghadasian MH. Pharmacological properties of plant sterols: in vivo and in vitro observations. Life Sci., 67, 605-615 (2000).

32) Dumolt JH, Rideout TC. The lipid-lowering effects and associated mechanisms of dietary phytosterol supplementation. Curr. Pharm. Des., 23, 5077-5085 (2017).

33) Pawlak M, Lefebvre P, Staels B. Molecular mechanism of PPAR $\alpha$ action and its impact on lipid metabolism, inflammation and fibrosis in non-alcoholic fatty liver disease. J. Hepatol., 62, 720-733 (2015).

34) Oswal DP, Balanarasimha M, Loyer JK, Bedi S, Soman FL, Rider SD Jr, Hostetler HA. Divergence between human and murine peroxisome proliferator-activated receptor alpha ligand specificities. $J$. Lipid Res., 54, 2354-2365 (2013).

35) Mukherjee R, Jow L, Noonan D, McDonnell DP. Human and rat 
peroxisome proliferator activated receptors (PPARs) demonstrate similar tissue distribution but different responsiveness to PPAR activators. J. Steroid Biochem. Mol. Biol., 51, 157-166 (1994).

36) Krey G, Braissant O, L'Horset F, Kalkhoven E, Perroud M, Parker MG, Wahli W. Fatty acids, eicosanoids, and hypolipidemic agents identified as ligands of peroxisome proliferator-activated receptors by coactivator-dependent receptor ligand assay. Mol. Endocrinol., 11, 779-791 (1997)

37) Aoyama T, Peters JM, Iritani N, Nakajima T, Furihata K, Hashimoto T, Gonzalez FJ. Altered constitutive expression of fatty acid-metabolizing enzymes in mice lacking the peroxisome proliferator-activated receptor $\alpha$ (PPAR $\alpha$ ). J. Biol. Chem., 273, 5678-5684 (1998).

38) Gulick T, Cresci S, Caira T, Moore DD, Kelly DP. The peroxisome proliferator-activated receptor regulates mitochondrial fatty acid oxidative enzyme gene expression. Proc. Natl. Acad. Sci. U.S.A., 91, 11012-11016 (1994).

39) Rodríguez JC, Gil-Gómez G, Hegardt FG, Haro D. Peroxisome proliferator-activated receptor mediates induction of the mitochondrial 3-hydroxy-3-methylglutaryl-CoA synthase gene by fatty acids. J. Biol. Chem., 269, 18767-18772 (1994).

40) Yamazaki N, Shinohara Y, Shima A, Terada H. High expression of a novel carnitine palmitoyltransferase I like protein in rat brown adipose tissue and heart: isolation and characterization of its cDNA clone. FEBS Lett., 363, 41-45 (1995).

41) McGarry JD, Brown NF. The mitochondrial carnitine palmitoyltransferase system. From concept to molecular analysis. Eur. J. Biochem., 244, 1-14 (1997).

42) Fiamoncini J, Turner N, Hirabara SM, Salgado TM, Marçal AC, Leslie S, da Silva SM, Deschamps FC, Luz J, Cooney GJ, Curi R. Enhanced peroxisomal b-oxidation is associated with prevention of obesity and glucose intolerance by fish oil-enriched diets. Obesity (Silver Spring), 21, 1200-1207 (2013).

43) Wooten JS, Nick TN, Seija A, Poole KE, Stout KB. High-fructose intake impairs the hepatic hypolipidemic effects of a high-fat fishoil diet in C57BL/6 mice. J. Clin. Exp. Hepatol., 6, 265-274 (2016).

44) Feillet-Coudray C, Aoun M, Fouret G, Bonafos B, Ramos J, Casas F, Cristol JP, Coudray C. Effects of long-term administration of sat- urated and $n-3$ fatty acid-rich diets on lipid utilisation and oxidative stress in rat liver and muscle tissues. Br. J. Nutr., 110, 1789-1802 (2013).

45) Brandt JM, Djouadi F, Kelly DP. Fatty acids activate transcription of the muscle carnitine palmitoyltransferase I gene in cardiac myocytes via the peroxisome proliferator-activated receptor $\alpha$. J. Biol. Chem., 273, 23786-23792 (1998).

46) Louet JF, Chatelain F, Decaux JF, Park EA, Kohl C, Pineau T, Girard J, Pegorier JP. Long-chain fatty acids regulate liver carnitine palmitoyltransferase I gene (L-CPT I) expression through a peroxisome-proliferator-activated receptor $\alpha$ (PPAR $\alpha)$-independent pathway. Biochem. J., 354, 189-197 (2001).

47) Ide T, Ontko JA. Increased secretion of very low density lipoprotein triglyceride following inhibition of long chain fatty acid oxidation in isolated rat liver. J. Biol. Chem., 256, 10247-10255 (1981).

48) Laker ME, Mayes PA. The immediate and long term effects of clofibrate on the metabolism of the perfused rat liver. Biochem. Pharmacol., 28, 2813-2827 (1979).

49) He J, Lee JH, Febbraio M, Xie W. The emerging roles of fatty acid translocase/CD36 and the aryl hydrocarbon receptor in fatty liver disease. Exp. Biol. Med. (Maywood), 236, 1116-1121 (2011).

50) Inoue M, Ohtake T, Motomura W, Takahashi N, Hosoki Y, Miyoshi S, Suzuki Y, Saito H, Kohgo Y, Okumura T. Increased expression of PPAR $\gamma$ in high fat diet-induced liver steatosis in mice. Biochem. Biophys. Res. Commun., 336, 215-222 (2005).

51) Yamazaki T, Shiraishi S, Kishimoto K, Miura S, Ezaki O. An increase in liver PPAR $\gamma 2$ is an initial event to induce fatty liver in response to a diet high in butter: PPAR $\gamma 2$ knockdown improves fatty liver induced by high-saturated fat. J. Nutr. Biochem., 22, 543-553 (2011).

52) Nishikawa S, Sugimoto J, Okada M, Sakairi T, Takagi S. Gene expression in livers of BALB/C and C57BL/6J mice fed a high-fat diet. Toxicol. Pathol., 40, 71-82 (2012).

53) Yuan F, Wang H, Tian Y, Li Q, He L, Li N, Liu Z. Fish oil alleviated high-fat diet-induced non-alcoholic fatty liver disease via regulating hepatic lipids metabolism and metaflammation: a transcriptomic study. Lipids Health Dis., 15, 20 (2016). 